ELORE (ISSN 1456-3010), vol. $18-1 / 2011$.

Julkaisija: Suomen Kansantietouden Tutkijain Seura ry. [http://www.elore.fi/arkisto/1_11/kirjat_tuori.pdf]

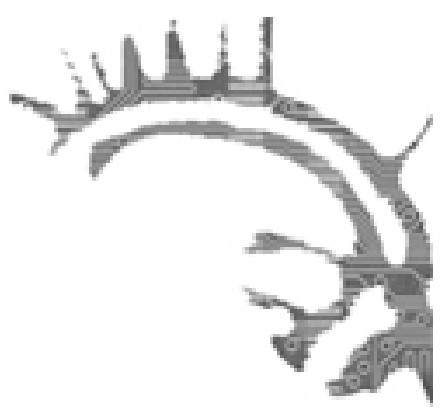

KIRJA-ARVIO

\title{
VIRANOMAISTOIMINTA KOHTAA KULTTUURISTA ERILAISUUTTA
}

HAMMAR-SUUTARI, SARI 2009: Asiakkaana erilaisuus. Kulttuurien välisen viranomaistoiminnan etnografia. Joensuun yliopiston Karjalan tutkimuslaitoksen julkaisuja 147. Joensuu: Joensuun yliopisto. 267 sivua.

\section{$\underline{\text { Salla Tuori }}$}

Sari Hammar-Suutarin väitöstutkimus Asiakkaana erilaisuns. Kulttunrien välisen viranomaistoiminnan etnografia käsittelee viranomaisten valmiuksia kohdata erilaisuutta ja heidän käsityksiään tasa-arvosta ja yhdenvertaisuudesta. Yhteen kysymykseen tiivistettynä tutkimuksen ydin on siinä, "[m]iten kulttuurinen monimuotoisuus vaikuttaa viranomaistyöhön Suomessa" (s. 34). Hammar-Suutarin tutkimuksesta saa hyvän kuvan suomalaisen viranomaistoiminnan suhteesta kulttuuriseen erilaisuuteen. Kulttuurisen erilaisuuden kohtaamista tarkastellaan viranomaistyön institutionaalisten ehtojen sekä viranomaiskulttuurin ja siihen liittyvien vuorovaikutustilanteen roolien kautta. Vaikka pääpaino onkin viranomaisten näkökulmassa, on tutkimuksessa selvitetty haastatteluin myös ulkomaalaistaustaisten asiantuntijoiden näkemyksistä viranomaistyöstä. Tutkimuksen selkeänä tavoitteena on osallistua sekä tieteelliseen keskusteluun suomalaisesta monikulttuurisuudesta että tarjota välineitä käytännön työhön. Tämä on ehdottomasti työn vahvuus.

\section{TOIMINNAN ETNOGRAFIAA MAAHANMUUTTOTUTKIMUKSEN KENTÄLLÄ}

Hammar-Suutari kutsuu metodologiaansa toiminnan etnografiaksi, jossa yhdistyvät etnografinen tutkimusote ja toimintatutkimus. Moninainen tutkimusaineisto ja 
lähestymistapa tekevätkin työstä erityisen kiinnostavan. Itseäni kiinnosti erityisesti toimintatutkimuksellinen osuus, jossa tutkija toteutti kolmen eri viranomaistahon kanssa pienimuotoisen kehittämishankkeen. Viranomaisia tutkimuksessa edustavat KELA, työvoimatoimisto ja sosiaalitoimisto. Etnografia koostuu ennen kaikkea haastatteluista ja epäilemättä myös tutkijan pitkästä kokemuksesta monikulttuurisen työn kentällä, vaikka tätä ei tuoda analyysissä kovin paljon esille. Haastatteluaineisto on laaja (65 henkilöä), ja se koostuu neljästä erilaisesta ryhmästä. Ensimmäisenä ryhmänä on erään monikulttuurisuusprojektin (MORO! Joensuu) toimintaryhmän jäsenet ja toinen koostuu avainviranomaisista eli julkisten sosiaalipalvelujen asiakaspalvelutehtävissä toimivista henkilöistä. Kolmannen ryhmän muodostavat "suhteellisen vähän aikaa Suomessa olleet maahanmuuttajat" ja neljännen asiantuntijat eli ulkomaalaistaustaiset henkilöt ja romanikulttuurin edustajat, joilla on runsaasti kokemusta viranomaistyöstä. Tutkimus on metodologisesti perusteellinen ja järjestelmällisesti toteutettu kahdessa eri vaiheessa, joita Hammar-Suutari kutsuu taustoittavaksi ja kohdennetuksi tutkimusvaiheeksi.

Teoreettisesti työ liikkuu vahvasti etnisten suhteiden ja muuttoliikkeen tutkimuksen kentällä. Tutkimuksesta voikin havaita, että kyseinen kenttä on kasvanut melko laajaksi myös Suomessa. Kulttuurinen monimuotoisuus ja monikulttuurisuus liittyvät tässä työssä nimenomaan etnis-kulttuurisiin eroihin. Työssä pohditaan muutamassa kohdassa (esim. s. 215) sitä, millä tavalla viranomaistoiminnassa kulttuurinen monimuotoisuus ymmärretään melko kapeasti kulttuurin, maahanmuuttajuuden ja etnisyyden kautta. Kuten Hammar-Suutari toteaa, nämä ovat kuitenkin vain joitain esiin tulevia eroja viranomaisten ja asiakkaiden kohtaamisissa. Tässä kohdin jäin miettimään, olisiko tutkimukseen tullut uusia näkökulmia, mikäli kirjoittaja olisi sijoittanut tutkimustaan laajempaan tutkimukselliseen kontekstiin nimenomaan erilaisten erojen näkökulmasta. Miltä tämän tutkimuksen tulokset olisivat näyttäneet, jos niitä olisi tarkasteltu esimerkiksi suhteessa tutkimuksiin vammaisten tai seksuaalivähemmistöjen kohtaamisista viranomaisten kanssa? Se olisi saattanut antaa mahdollisuuksia pohtia yhtäältä hieman tarkemmin sitä, millä tavalla nimenomaan etnis-kulttuuriseksi ymmärretyt erot vaikuttavat viranomaistyöhön. Toisaalta tällä tavalla olisi voinut pohtia erilaisuutta myös laajemmasta näkökulmasta. Tutkimuksessa pysytään varsin järjestelmällisesti etnisyyteen, maahanmuuttoon ja monikulttuurisuuteen liittyvässä kirjallisuudessa ja tutkimusnäkökulmissa.

Tutkimuksen ydinkäsitteitä ovat kulttuurin ja erilaisuuden lisäksi tasa-arvo ja yhdenvertaisuus, jotka ovat sekä viranomaistyön keskeisiä ohjenuoria että tutkimuksessa tarkasteltavia käsitteitä. Laajemmilla lukuretkillä Hammar-Suutari olisi voinut ehkä syventää ja lisätä yhdenvertaisuudesta ja tasa-arvosta käytävän keskustelun analyyttisyyttä. Sukupuolten välistä tasa-arvoa käsittelevässä tutkimuksessa tasa-arvoa ja yhdenvertaisuutta on pohdittu paljon myös käsitteellisistä näkökulmista. Näistä saattaisi olla hyötyä esimerkiksi sen pohdinnassa, minkälaisiin taustaolettamuksiin erilaiset tasa-arvon käsitteellistämisen tavat liittyvät. 


\section{KULTTUURI EROJEN YMMÄRTÄMISEN KÄSITTEENÄ}

Kulttuurin käsitteestä käydään teoksessa havainnollista ja melko perusteellista keskustelua. Tämä onkin tärkeää, sillä kulttuuri vaikuttaa (edelleen) olevan keskeisin tapa ymmärtää eroja viranomaistyössä ja varmasti myös laajemmin suomalaisen monikulttuurisuuden kentällä. Tämänkin tutkimuksen perusteella kulttuuria voisi ajatella sellaisena maailman jäsennystapana, jolla on Suomessa voimaa. Sekä viranomaiset että ulkomaalaistaustaiset ja romanikulttuurin asiantuntijat kaipasivat "kulttuuritulkkausta" kielellisen tulkkauksen lisäksi. Hankaluudet asiakaskontakteissa nimettiin usein kulttuuriin tai kielellisen ymmärtämiseen liittyviksi - vaikka ymmärtäisikin kieltä, voi silti olla hankalaa ymmärtää mitä jokin käsite pitää sisällään tai millä tavalla viranomaisten tehtävät on Suomessa jaettu. Vaikuttaa siltä, että yleisen "kulttuurin" käsitteen nähdään kattavan myös eroja byrokraattisissa järjestelmissä tai viranomaiskulttuureissa.

Asiakaskohtaamisia sosiaalipalveluissa tarkastellaan väitöskirjassa erityisesti viranomaisten näkökulmasta. Hammar-Suutari erittelee työssä kiinnostavasti viranomaisten erilaisia odotuksia asiakkaita kohtaan ja sitä, miten "vääränlainen" käytös vaikuttaa asiakaspalvelutilanteeseen. Se mitä viranomaiset nimeävät "kulttuurieroiksi" tarkoittaa käytännössä joko oletetusta asiakkaasta poikkeavaa ulkonäköä tai käyttäytymistä. Olisin mielelläni lukenut vielä enemmän siitä, minkälaisia muotoja "kulttuuri" tai "kulttuurierot" saavat käytännön työssä ja arkisissa kohtaamisissa. Nämä jäävät hieman yleisiksi, ja kirjoittaja toteaakin, että haastateltavien ei ollut aina helppoa eritellä, mitä he kulttuurilla tarkoittavat tai mistä ajattelevat kulttuurin koostuvan. Viranomaisten näkökulmasta kulttuurit käsitetään enimmäkseen erillisinä "yksikköinä". Tätä näkemystä haastamaan Hammar-Suutari tuo kulttuurin prosessinomaisen ymmärtämisen. Tämä on arvokasta, sillä teosta tullaan varmasti lukemaan myös monikulttuurisuustyötä tekevien parissa.

Kulttuurin lisäksi viranomaiset näkivät sekä omat (ja kollegoidensa) että asiakkaiden asenteet merkittävinä tekijöinä siinä, miten asiakaskontaktit onnistuvat. Ei ole ehkä kovin yllättävää, että nimenomaan kulttuuri ja asenteet ovat keskeisiä käsitteitä kulttuurisen erilaisuuden ja siihen liittyvien kohtaamisten jäsentämisessä. Valtasuhteet, rakenteet tai institutionaaliset käytännöt ovat saaneet vähemmän huomiota julkisessa keskustelussa ja pitkään myös tutkimuksessa. Kuten Hammar-Suutari kirjoittaa yhteenvedossa

[e]dellä esitetty arvio suomalaisen yhteiskunnan suhteesta monikulttuurisuuteen luo kuvan käsityksestä, jonka mukaan yhteiskunta rakentuu kuvitteellisen yhtenäiskulttuurin aineksista, ja jossa palveluja tuotetaan vastaamaan näin syntyneen, myös kuvitteellisen, keskivertoasiakkaan tarpeisiin. Joutuminen näin tekemisiin vieraiden elementtien kanssa asettaa olemassa olevan järjestelmän koetukselle, ja haasteeseen yritetään vastata ensisijaisesti olemassa olevien käytäntömallien mukaan. (s. 217)

Ehkä juuri asenteiden korostaminen johtaa siihen, että muutospaineet ja kulttuuriseen monimuotoisuuteen vastaaminen painottuvat yksittäisille virkailijoille, kun 
taas perusteellisempia muutoksia viranomaiskäytäntöihin on hankalampi toteuttaa. Toivottavasti tämä tutkimus osaltaan vaikuttaa myös siihen, millä tavalla viranomaistoimintaa kehitetään suhteessa kulttuuriseen monimuotoisuuteen. Teoksessa esitellään muun muassa malli (s. 131), jonka avulla työyhteisöt voivat kehittää yhdenvertaisuuskäytäntöjään.

\section{EPÄVARMUUS, YHDENVERTAISUUS JA MONIMUOTOISUUS}

Sari Hammar-Suutari pohtii tutkimuksessaan sitä, millä tavoilla epävarmuus ja pelko vaikuttavat kohtaamisiin viranomaistyössä. Epävarmoja ovat asiakkaiden lisäksi myös viranomaiset. Epävarmuus lisää jäykkyyttä ja joustamattomuutta viranomaisten toiminnassa ja kasvattaa heidän kokemaansa stressiä. Asiakkaiden kokema epävarmuus johtaa sekin paitsi lisääntyvään stressiin myös toimintatapoihin, jotka hankaloittavat kanssakäymistä viranomaisten kanssa. Tutkimuksesta käy ilmi, että viranomaiskentällä on sekä halua että tarvetta lisätä kulttuuriseen monimuotoisuuteen liittyvää tietoa ja toimintavalmiuksia. Viranomaistyö on toki usein kiireistä eikä arjen keskellä ole välttämättä tähän tilaa. Todelliseen yhdenvertaisuuteen pyrkiminen vaatii myös panostusta.

Tutkimus on aineistoltaan laaja ja huolellisesti toteutettu. Olisinkin siksi kaivannut runsaampaa aineiston käsittelyä ja analyysiä. Esimerkiksi tapa, jolla kulttuurin ja asenteiden käsitteellistämistä arjen puheissa ja käytännöissä tarkastellaan, jää jossain määrin yleisluontoiseksi. Toimintatutkimuksellinen osio jää myös käsittelyltään melko kuvailevaksi. Osittain tämä johtuu varmasti väitöskirjan rakenteesta ja luonteesta metodologiaa, taustaa ja teoriaa tulee käsitellä perin pohjin, jolloin suuri osa kirjasta kuluu helposti taustoittamiseen. Lukisin mielelläni myös laajaan aineistoon pohjaavia tutkimusartikkeleita. Kirja sopii hyvin sekä tutkijoille että käytännön työtä tekeville, joita kiinnostavat monikulttuuriset käytännöt ja julkisten sosiaalipalvelujen analyysi. On ilahduttavaa lukea tutkimusta, jossa yhdistetään onnistuneesti teoreettisia ja toiminnallisia elementtejä.

VTT Salla Tuori toimii tutkijatohtorina Svenska social- och kommunalhögskolanissa Helsingin yliopistossa. 